\title{
IDENTIFIKASI JENIS DAN HABITAT JAMUR MAKROSKOPIS DI HUTAN LARANGAN ADAT RUMBIO KABUPATEN KAMPAR PROVINSI RIAU
}

\author{
Fadlan Nasution ${ }^{1}$, Sri Rahayu Prasetyaningsih ${ }^{2}$, Muhammad Ikhwan ${ }^{2}$ \\ ${ }^{1}$ Mahasiswa Fakultas Kehutanan Universitas Lancang Kuning \\ ${ }^{2}$ Staff Pengajar Fakultas Kehutanan Universitas Lancang Kuning \\ Jl. Yos Sudarso Km. 8 Rumbai. Pekanbaru \\ Email: Fadlanlee.nasution95@gmail.com, srirahayu_pn@yahoo.co.id,dan mmighwan@yahoo.com
}

\begin{abstract}
Mushrooms are one of the many types of organisms that play an important role in maintaining the balance and the nature of nature. As a country with extensive tropical rain forests with a high diversity of macroscopic mushroom species, in Indonesia's forests research on macroscopic mushroom diversity has not been widely practiced. Forest Prohibition of Rumbio Custom in Kampar District of Riau Province is one example of forest area in Indonesia which of course has high macroscopic mushroom diversity. The purpose of this study is to identify the types of Macroscopic Mushroom and Know the habitat of Macroscopic Fungi in Forest Area Prohibition of Rumbio Adat, Kampar regency of Riau Province.jamur using exploratory method with purposive sampling technique. The data obtained then analyzed by descriptiveexplorative method. Based on the results of research that has been done in the forest area of Rumbio Indigenous Ban found 30 types of Macroscopic mushrooms from 1 Division Basidiomycota namely, Amaroderma sp, Calocera cornea, Clytocybe sp, Collybia sp, Collybia sp1, Coltricia perennis, Coltricia cinnamomea, Crepidotus variabilis, Crepidotus herbarum, Coriolopsis Occidentalis, Daedinella sp, Fomitopsis pinicola, Fomes fomentarius, Fomes lignosus, Ganoderma sp, Ganoderma sp1, Hygrocybe miniata, Hydnellum sp, Lepiota cristata, Lepiota atrodisca, Lignosus rhinocerus, Marasmius andrasaceus, Marasmius foetidus, Marasmiellus sp, Mycena $\mathrm{sp}$, Polyporus sp, Polyporus sp1, Piptoporus betulinus, Ramariopsis kunzei, Schlzophyllum commune. The types of fungi found in this study are divided into 6 Order and 12 Family. The Order of Agaricales is the dominant group in the study site, since the number of families and species is most widely found in this study. The environmental conditions of the study sites are temperature $24-310 \mathrm{C}$, air humidity 75 $89 \%$, light intensity 125-1226 lux and soil pH 5.5-6,4. Macroscopic mushrooms that are found generally live on decayed wood and litter, and a small part live on live trees.
\end{abstract}

Keywords: Identification Of Types, Habitat, Makroskopis Mushroom,

\section{PENDAHULUAN}

Jamur merupakan satu diantara berbagai jenis organisme yang berperan penting dalam menjaga keseimbangan dan kelestarian alam. Dari segi ekologi jamur berperan sebagai dekomposer bersama dengan bakteri dan beberapa spesies protozoa, sehingga banyak 
membantu proses dekomposisi bahan organik untuk mempercepat siklus materi dalam ekosistem hutan. Dengan demikian, jamur ikut membantu menyuburkan tanah melalui penyediaan nutrisi bagi tumbuhan, sehingga hutan tumbuh dengan subur (Suharna, 1993 dalam Tampubolon 2010).

Jamur, khususnya kelompok jamur makroskopis atau makrofungi, merupakan kelompok utama organisme pendegradasi lignoselulosa karena mampu menghasilkan enzim-enzim pendegradasi lignoselulosa seperti selulase, ligninase, dan hemiselulase (Munir, 2006), sehingga siklus materi di alam dapat terus berlangsung. Selain itu, kelompok jamur makroskopis secara nyata mempengaruhi jaring-jaring makanan di hutan, kelangsungan hidup atau perkecambahan anakan-anakan pohon, pertumbuhan pohon, dan keseluruhan kesehatan hutan. Jadi, keberadaan jamur makroskopis adalah indikator penting komunitas hutan yang dinamis (Molina et al, 2001 dalam Tampubolon, 2010). Sejumlah 200.000 spesies dari 1,5 juta spesies jamur diperkirakan ditemukan di Indonesia, dimana hingga saat ini belum ada data pasti mengenai jumlah spesies jamur tersebut, yang telah berhasil diidentifikasi, dimanfaatkan, ataupun yang telah punah akibat ulah manusia (Gandjar et al., 2006 dalam Hayati 2013). Beberapa jenis jamur ada yang dapat dimanfaatkan sebagai makanan, khasiat obat, dan lain-lain serta ada juga jamur yang dapat mengakibatkan keracunan (Bahrun dan Muchroji, 2005).

Di antara jamur yang tumbuh secara alami, jamur merang (Volvariella volvacea) dan jamur kuping (Auricularia auricula) merupakan jamur konsumsi yang cukup disukai masyarakat. Jamur selain dapat di konsumsi, ada juga jamur yang diketahui berkhasiat obat yaitu jamur maitake (Grifola frondosa) yang dapat mencegah tumor dan kanker.

Sebagai negara yang memiliki hutan hujan tropis yang luas dengan keanekaragaman spesies jamur makroskopis yang tinggi, di hutan Indonesia penelitian mengenai keanekaragaman jamur makroskopis belum banyak dilakukan. Sampai saat ini data dan literatur mengenai keanekaragaman jamur makroskopis di Indonesia masih sangat terbatas. Di lain pihak, kita dihadapkan pada cepatnya laju penurunan keanekaragaman hayati baik oleh proses alamiah maupun oleh ulah manusia. Jika hal ini terus berlanjut, 
maka banyak spesies jamur makroskopis yang belum teridentifikasi mungkin akan segera punah. Oleh sebab itu, penelitian mengenai Identifikasi spesies jamur makroskopis perlu dilakukan secara intensif. Penelitian mengenai jenis jenis jamur di Riau salah satunya dilakukan oleh Wahyudi (2016) menemukan 25 jenis jamur di Arboretum Dipterocarpaceae Fakultas Kehutanan Universitas Lancang Kuning Pekanbaru.

Hutan Larangan Adat Rumbio yang berada di Kabupaten Kampar Provinsi Riau merupakan satu contoh kawasan hutan di Indonesia yang tentunya memiliki keanekaragaman jamur makroskopis yang tinggi. Di kawasan Hutan Larangan Adat Rumbio penelitian mengenai identifikasi jamur makroskopis, sejauh ini belum pernah dilakukan. Mengingat pentingnya peranan jamur makroskopis dalam suatu ekosistem hutan, seperti Hutan Larangan Adat Rumbio, maka penting dilakukan suatu penelitian untuk mengetahui jenis-jenis jamur makroskopis dan habitat di kawasan Hutan Larangan adat Rumbio. Selain itu penelitian tentang identifikasi jamur belum pernah dilakukan di Hutan Larangan Adat Rumbio. Penelitian ini bertujuan untuk mendapatkan data Jenis-jenis jamur makroskopis yang terdapat di kawasan Hutan Larangan Adat Rumbio, Kabupaten Kampar Provinsi Riau.

\section{METODE PENELITIAN}

Penelitian ini dilakukan dari bulan Mei Juni 2017 di Hutan Larangan Adat Rumbio, Kabupaten Kampar Riau. Alatalat yang dilakukan dalam penelitian ini adalah GPS, kamera digital, meteran, alat tulis, termohigrometer, $\mathrm{pH}$ meter, lux meter, kotak sampel dan oven. Sedangkan bahan yang digunakan adalah tally sheet, buku identifikasi jamur David L Largent (1973).

\section{HASIL DAN PEMBAHASAN}

Jumlah Jenis, Ordo dan Famili Jamur Makroskopis Di Hutan Larangan Adat Rumbio, Kecamatan Kampar Provinsi Riau

Berdasarkan hasil penelitian yang telah dilakukan dikawasan Hutan Larangan Adat Rumbio ditemukan 30 jenis jamur Makroskopis dari 1 Divisi Basidiomycota yaitu, Amaroderma sp, Calocera cornea, Clytocybe sp, Collybia sp, Collybia sp1, Coltricia perennis, Coltricia cinnamomea, Crepidotus variabilis, Crepidotus herbarum, 
Coriolopsis occidentalis, Daedinella sp, Fomitopsis pinicola, Fomes fomentarius, Fomes lignosus, Ganoderma sp, Ganoderma sp1, Hygrocybe miniata, Hydnellum sp, Lepiota cristata, Lepiota atrodisca, Lignosus rhinocerus, Marasmius andrasaceus, Marasmius foetidus, Marasmiellus sp, Mycena sp, Polyporus sp, Polyporus sp1, Piptoporus betulinus, Ramariopsis kunzei, Schlzophyllum commune. Jenis-jenis jamur yang ditemukan dalam penelitian ini terbagi kedalam 6 Ordo dan 12 Famili. Ordo Agaricales merupakan kelompok yang mendominasi dalam lokasi penelitian, karena jumlah famili dan spesiesnya paling banyak ditemukan dalam penelitian ini . Ordo Agaricales yang ditemukan terdiri dari 7 famili dan 13 spesies. Famili dari ordo Agaricales yakni Clavariaceae, Mycenaceae, Agaricaceae, Marasmiaceae, Crepidotaceae, Higroporaceae dan Tricholomateceae. Marasmiaceae dan Tricholomateceae merupakan famili yang mendominasi di ordo Agaricales.

Untuk melihat jumlah ordo dapat dilihat pada Tabel 1.

\section{Tabel 1. Jumlah Ordo Jamur Makroskopis Di Hutan Larangan Adat Rumbio}

\begin{tabular}{|c|c|c|c|}
\hline No & Ordo & $\begin{array}{c}\text { Jumlah } \\
\text { Family }\end{array}$ & $\begin{array}{c}\text { Jumlah } \\
\text { Jenis }\end{array}$ \\
\hline 1 & Agaricales & 7 & 13 \\
\hline 2 & Polyporales & 1 & 12 \\
\hline 3 & Aphylloporales & 1 & 1 \\
\hline 4 & Dacrymycenatales & 1 & 1 \\
\hline 5 & Hymenochaetales & 1 & 2 \\
\hline 6 & Theleporales & 1 & 1 \\
\hline & Jumlah & 12 & 30 \\
\hline
\end{tabular}

Sumber: Data Hasil Olahan 2017

Persentase jumlah jenis jamur Makroskopis pada masing-masing ordo di Hutan Larangan Adat Rumbio disajikan dalam Gambar 1.

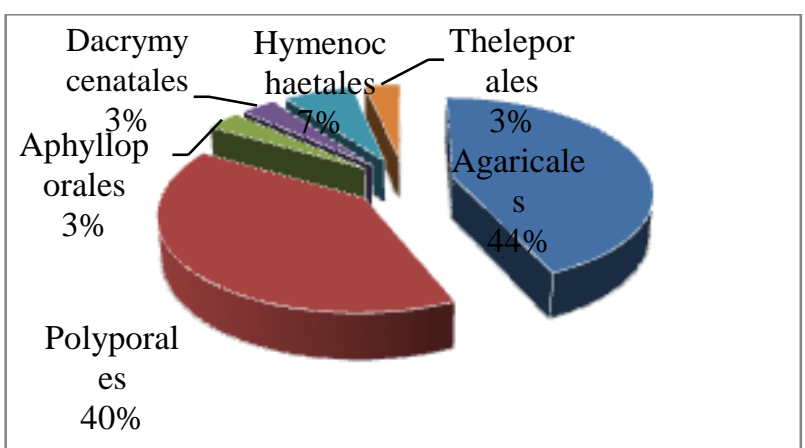

\section{Gambar 1. Persentase Jumlah Jenis Jamur Pada Masing- Masing Ordo}

Pada penelitian identifikasi jamur Makroskopis yang dilakukan di Hutan Larangan Adat Rumbio diketahui bahwa jenis jamur yang paling banyak ditemukan pada setiap Ordo adalah Ordo Agaricales memiliki persentase tertinggi yaitu $44 \%$. Hal ini menunjukkan bahwa kemampuan Ordo Agaricales 
beradaptasi dengan baik terhadap lingkungan Hutan Larangan Adat Rumbio serta sesuai sebagai habitat bagi ordo ini. Ordo Agaricales sendiri adalah kelompok jamur Basidiomycota makroskopis yang paling familiar dengan bentuk seperti payung (Arora 1986, dalam Tampubolon 2010). Anggota ordo Agaricales sangat banyak dan kompleks. Dalam beberapa penelitian, anggota ordo ini selalu ditemukan dan sering dengan jumlah anggota terbesar yang ditemukan dalam penelitian-penelitian tersebut.

Jumlah famili Jamur Makroskopis Di Hutan Larangan Adat Rumbio dapat dilihat pada Tabel 4.

Tabel 2. Jumlah Famili Jamur Makroskopis Di Hutan Adat Rumbio

\begin{tabular}{|c|c|c|}
\hline No & Famili & Jumlah Jenis \\
\hline 1 & Polyporaceae & 12 \\
\hline 2 & Marasmiaceae & 3 \\
\hline 3 & Tricholomataceae & 3 \\
\hline 4 & Agariaceae & 2 \\
\hline 5 & Crepidotaceae & 2 \\
\hline 6 & Hymenochaetaceae & 2 \\
\hline 7 & Mycenaceae & 1 \\
\hline 8 & Higroporaceae & 1 \\
\hline 9 & Schizophylaceae & 1 \\
\hline 10 & Clavariaceae & 1 \\
\hline 11 & Dacrymycetaceae & 1 \\
\hline 12 & Hydnellaceae & 1 \\
\hline & Jumlah & 30 \\
\hline
\end{tabular}

Sumber: Data Hasil Olahan 2017
Jumlah jenis jamur makroskopis pada setiap famili yang ditemukan di Hutan Larangan Adat Rumbio diketahui bahwa famili Polyporaceae memiliki jumlah jenis jamur yang paling banyak yaitu 12 jenis. Sedangkan famili dengan jumlah jenis jamur yang paling sedikit adalah Mycenaceae, Higroporaceae, Schizophylaceae,

Clavariaceae, Dacrymycetaceae dan Hydnellaceae yang masing-masing hanya ditemukan 1 jenis, sebagaimana dapat dilihat pada Tabel 4.

Persentase jumlah Jenis Jamur Makroskopis Pada Setiap Famili Di Hutan Adat Larangan Adat Rumbio disajikan dalam Gambar 2.

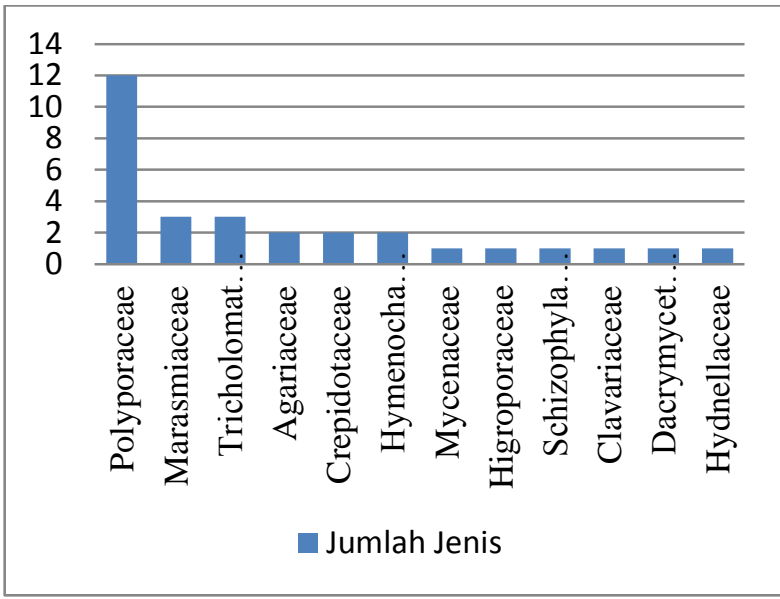
Gambar 2. Persentase Jumlah Jenis Jamur Makroskopis Pada Masing-Masing Famili Di Hutan Larangan Adat Rumbio


Habitat Jamur Makroskopis Di Kawasan Hutan Larangan Adat Rumbio

\section{Kondisi Faktor Lingkungan}

Hasil penelitian yang telah dilakukan untuk pengamatan kondisi faktor lingkungan lokasi penelitian yang dilakukan setiap hari pada pagi, siang dan sore selama 7 hari yaitu, $\mathrm{pH}$ tanah, suhu, kelembaban udara, dan intensitas cahaya.

Adapun kondisi faktor lingkungan lokasi penelitian dapat dilihat pada Tabel 5 .

Tabel 3. Kondisi Faktor Lingkungan di Hutan Larangan Adat Rumbio

\begin{tabular}{|c|c|}
\hline Faktor Lingkungan & Hasil Pengukuran \\
\hline $\mathrm{pH}$ Tanah & $5.5-6.4$ \\
\hline Suhu & $23-31\left({ }^{\circ} \mathrm{C}\right)$ \\
\hline Kelembaban & $75-89(\%)$ \\
\hline Intensitas Cahaya & $125-1226($ Lux $)$ \\
\hline
\end{tabular}

Sumber: Data Hasil Olahan 2017

Pada kondisi lingkungan di Hutan Larangan Adat Rumbio, permukaaan tanah banyak ditutupi oleh serasahserasah daun, terdapat pohon-pohon besar dengan kanopi yang tertutup rapat, dan beberapa pohon tumbang dan mati. Pada lokasi penelitian kisaran suhu udara $23-31{ }^{\circ} \mathrm{C}$, kelembaban 75 89\%, pH tanah 5,5-6,4, dan intensitas cahaya 125-1226 lux (Tabel 3). Berdasarkan kondisi tersebut sangat mendukung untuk pertumbuhan jamur terutama jamur makroskopis. Hal ini karena jamur dapat tumbuh dengan $\mathrm{pH}$ optimum antara 5,5-7,5 (Gunawan,2001) dan kelembaban relatif sebesar $75-90 \%$ (Suhardiman, 1995).

Menurut Gandjar et al., (2006) dalam Khosuma (2012), jamur dapat tumbuh pada kisaran kelembaban 70 $90 \%$. Cahaya sangat berpengaruh terhadap reproduksi jamur. Spektrum cahaya yang relatif terhadap pertumbuhan jamur antara 380-720 lux. Purdy (1956) dalam Tampubolon (2010) menyatakan bahwa intensitas penyinaran yang tinggi akan menghambat pertumbuhan populasi jamur, karena akan menghambat pembentukan struktur alat-alat reproduksi dan spora jamur. Hasil penelitian yang dilakukan oleh Triroh Wahyudi (2016) di Arboretum Dipterocarpaceae Fakultas Kehutanan Universitas Lancang Kuning. Kondisi faktor lingkungan jamur tidak jauh berbeda dengan penelitian di hutan Larangan Adat Rumbio. Adapun kondisi lingkungan di Arboretum Fakultas Kehutanan, kisaran suhu udara 23-32 C, kelembaban 74-87\%, pH tanah 5,6 - 6,5 dan intensitas cahaya 165-933 lux. 
Tabel 4. Spesies Jamur Makroskopis di Hutan Larangan Adat Rumbio Kabupaten Kampar Provinsi Riau.

\begin{tabular}{|c|c|c|c|c|c|c|c|c|}
\hline \multirow{2}{*}{ Ordo } & \multirow{2}{*}{ Famili } & \multirow{2}{*}{ Spesies } & \multicolumn{6}{|c|}{ Jalur } \\
\hline & & & 1 & 2 & 3 & 4 & 5 & 6 \\
\hline Aphylloporales & Schizophylaceae & Schyzophylum commun & $\sqrt{ }$ & - & - & $\sqrt{ }$ & - & - \\
\hline \multirow{13}{*}{ Agaricales } & Clavariaceae & Ramariopsis kunzei & $\sqrt{ }$ & - & - & $\sqrt{ }$ & - & $\sqrt{ }$ \\
\hline & \multirow{2}{*}{ Crepidotaceae } & Crepidotus variabilis & - & $\sqrt{ }$ & - & - & $\sqrt{ }$ & - \\
\hline & & Crepidotus herbarum & - & - & - & - & $\sqrt{ }$ & - \\
\hline & \multirow{2}{*}{ Agaricaceae } & Lepiota atrodisca & - & - & - & $\sqrt{ }$ & - & - \\
\hline & & Lepiota cristata & $\sqrt{ }$ & $\sqrt{ }$ & - & - & - & $\sqrt{ }$ \\
\hline & Mycenaceae & Mycena sp & - & $\sqrt{ }$ & - & - & - & - \\
\hline & \multirow{3}{*}{ Marasmiaceae } & Marasmius fotidus & $\sqrt{ }$ & $\sqrt{ }$ & $\sqrt{ }$ & $\sqrt{ }$ & $\sqrt{ }$ & $\sqrt{ }$ \\
\hline & & Marasmius andrasaceus & - & $\sqrt{ }$ & - & - & $\sqrt{ }$ & $\sqrt{ }$ \\
\hline & & Marasmiellus $s p$ & - & $\sqrt{ }$ & $\sqrt{ }$ & - & $\sqrt{ }$ & - \\
\hline & \multirow{3}{*}{ Tricholomataceae } & Collybia sp & - & - & - & $\sqrt{ }$ & - & - \\
\hline & & Collybia sp1 & $\sqrt{ }$ & $\sqrt{ }$ & $\sqrt{ }$ & - & - & - \\
\hline & & Clytocybe $s p$ & - & - & $\sqrt{ }$ & $\sqrt{ }$ & - & - \\
\hline & Higroporaceae & Higrocybe miniata & $\sqrt{ }$ & - & $\sqrt{ }$ & - & $\sqrt{ }$ & $\sqrt{ }$ \\
\hline \multirow{12}{*}{ Polyporales } & \multirow{12}{*}{ Polyporaceae } & Coriolopsis occidentalis & - & - & - & - & $\sqrt{ }$ & - \\
\hline & & Amaroderma sp & $\sqrt{ }$ & $\sqrt{ }$ & - & - & $\sqrt{ }$ & - \\
\hline & & Polyporus sp & $\sqrt{ }$ & $\sqrt{1}$ & $\sqrt{ }$ & $\sqrt{1}$ & $\sqrt{ }$ & $\sqrt{ }$ \\
\hline & & Polyporus sp1 & - & - & $\sqrt{ }$ & $\sqrt{ }$ & $\sqrt{ }$ & $\sqrt{ }$ \\
\hline & & Fomes lignosus & - & $\sqrt{ }$ & $\sqrt{ }$ & - & - & - \\
\hline & & Fomes fomentarius & $\sqrt{ }$ & - & - & - & - & - \\
\hline & & Deadinella $s p$ & - & $\sqrt{ }$ & $\sqrt{ }$ & - & - & - \\
\hline & & Ganoderma sp & $\sqrt{ }$ & - & - & - & - & - \\
\hline & & Ganoderma sp1 & - & - & - & $\sqrt{ }$ & $\sqrt{ }$ & $\sqrt{ }$ \\
\hline & & Fomitopsis pinicola & - & - & - & $\sqrt{ }$ & - & - \\
\hline & & Lignosus rhinocherus & - & $\sqrt{ }$ & $\sqrt{ }$ & $\sqrt{ }$ & - & - \\
\hline & & Piptoporus betulinus & - & - & - & - & $\sqrt{ }$ & - \\
\hline
\end{tabular}




\begin{tabular}{|l|l|l|l|l|l|l|l|l|}
\hline \multirow{2}{*}{ Hymenochaetale } & \multirow{2}{*}{ Hymenochaetacea } & Coltricia perennis & - & $\sqrt{ }$ & $\sqrt{ }$ & $\sqrt{ }$ & $\sqrt{ }$ & $\sqrt{ }$ \\
\cline { 3 - 9 } & & Coltricia cinamomea & $\sqrt{ }$ & - & - & - & - & - \\
\hline Dacrymycetales & Dacrymycetaceae & Calocera cornea & $\sqrt{ }$ & $\sqrt{ }$ & - & - & - & $\sqrt{ }$ \\
\hline Theleporales & Hydnellaceae & Hydnellum sp & $\sqrt{ }$ & - & $\sqrt{ }$ & $\sqrt{ }$ & - & - \\
\hline
\end{tabular}

Keterangan :

$(\sqrt{ })$ : Ditemukan

( - ) : Tidak ditemukan

Dari 30 jenis jamur makroskopis yang ditemukan, seluruhnya termasuk ke dalam divisi Basiodiomycota. Hal ini sesuai dengan pendapat Dwidjoseputro (1976) yang menyatakan bahwa jamur yang termasuk jamur makroskopis adalah sebagian besar divisi Basiodiomycota dan sebagian kecil dari divisi Ascomycota. Menurut Gunawan (2001) jamur makroskopis merupakan cendawan sejati yang ukurannya relatif besar (makroskopik), dapat dilihat dengan kasat mata, dapat dipegang atau dipetik dengan tangan, dan bentuknya mencolok. Jamur makroskopis mempunyai bentuk tubuh buah seperti payung, struktur reproduksinya berbentuk bilah (gills) yang terletak pada permukaan bawah dari payung atau tudung (Sinaga, 2005).

Pada penelitian identifikasi jamur makroskopis yang dilakukan di Hutan Larangan Adat Rumbio diketahui bahwa jenis jamur yang paling banyak ditemukan pada setiap famili adalah dari famili Polyporaceae, yaitu sebanyak 12 jenis (Tabel 4). Hasil ini sama dengan penelitian Imon (2008), Muniarti (2010), dan Juminarti (2011) yang menyatakan bahwa famili Polyporaceae memiliki jenis jamur yang paling banyak ditemukan. Muniarti (2010) sebanyak 17 jenis, dan Juminarti (2011) sebanyak 16 jenis. Hal ini karena Polyporaceae memiliki tubuh buah yang besar dan berstruktur keras berkayu (McKnight dan Vera, 1987). Tubuh buah pileus memiliki ciri umum berbentuk kipas dengan permukaan himenium berupa lubanglubang kecil yang disebut pores atau modifikasinya. Tubuh buahnya berkayu, tebal dan kasar (Dwidjoseputro, 1978; Arora, 1986). sehingga famili Polyporaceae memiliki kemampuan adaptasi yang baik di berbagai tempat pada ketinggian yang berbeda dengan kelembaban yang tinggi (Tampubolon, dkk., 2013). 
Jamur yang ditemukan dan mendominasi di setiap jalur adalah jamur Polyporus $s p$ dari famili Polyporaceae yang termasuk kedalam Ordo Polyporaceae, Hal ini terjadi karena cahaya, suhu, kelembaban dan air secara ekologis cocok untuk kondisi habitatnya. Cahaya dengan intensitas yang rendah sangat penting dalam pembentukan tubuh buah, pembentukan spora, atau pelepasan spora.

Jamur yang ditemukan di hutan Larangan Adat Rumbio, ada yang tidak ditemukan pada penelitian Triroh Wahyudi (2016) di Arboretum Unilak, yaitu seperti jamur Calocera cornea, Daedinella sp, Coriolopsis occidentalis, Higrocybe miniata, Hydnellum $s p$, Amaroderma sp, Lepiota Cristata, Piptorus betulinus, dan Marasmius

Tabel 5. Substrat Spesies Jamur Makroskopis Yang ditemukan di Hutan Larangan Adat Rumbio

\begin{tabular}{|l|l|c|c|c|}
\hline \multirow{2}{*}{ No } & \multirow{2}{*}{ Spesies } & \multicolumn{3}{c|}{ Substrat } \\
\cline { 3 - 5 } & & Kayu Lapuk & Serasah/Tanah & Pohon Hidup \\
\hline 1 & Schyzophylum commune & + & - & - \\
\hline 2 & Ramariopsis kunzei & - & + & - \\
\hline 3 & Crepidotus variabilis & + & - & - \\
\hline 4 & Crepidotus herbarum & + & - & - \\
\hline 5 & Lepiota atrodisca & + & + & - \\
\hline 6 & Lepiota cristata & + & + & - \\
\hline 7 & Mycena sp & + & + & - \\
\hline 8 & Marasmius fotidus & + & - & - \\
\hline 9 & Marasmius andrasaceus & - & + & - \\
\hline 10 & Marasmiellus $s p$ & + & + & - \\
\hline 11 & Collybia $s p$ & + & - & + \\
\hline 12 & Collybia $s p 1$ & - & & \\
\hline
\end{tabular}
faktor lingkungan yang berbeda di setiap daerah. Suin (2002) dalam Tampubolon (2010), menyatakan faktor lingkungan sangat menentukan penyebaran dan pertumbuhan suatu organisme. Setiap spesies hanya dapat hidup pada kondisi abiotik yang berada dalam kisaran toleransi tertentu yang cocok bagi organisme tersebut.

\section{Substrat Jamur Makroskopis}

Sebagian besar dari 30 spesies jamur Makroskopis yang ditemukan, hidup pada kayu lapuk. Habitat lain adalah serasah/tanah dan pohon hidup. Habitat seluruh spesies jamur Makroskopis yang ditemukan disajikan dalam Tabel 7. 


\begin{tabular}{|c|l|c|c|c|}
\hline 13 & Clytocybe sp & + & + & - \\
\hline 14 & Higrocybe miniata & + & + & - \\
\hline 15 & Coriolopsis occidentalis & + & - & - \\
\hline 16 & Amaroderma sp & - & + & - \\
\hline 17 & Polyporus sp & + & + & - \\
\hline 18 & Polyporus sp1 & + & + & + \\
\hline 19 & Fomes lignosus & - & - & - \\
\hline 20 & Fomes fomentarius & + & - & + \\
\hline 21 & Deadinella sp & + & - & + \\
\hline 22 & Ganoderma sp & - & - & - \\
\hline 23 & Ganoderma sp1 & - & - & - \\
\hline 24 & Fomitopsis pinicola & + & - & - \\
\hline 25 & Lignosus rhinocherus & - & + & - \\
\hline 26 & Piptoporus betulinus & + & - & - \\
\hline 27 & Coltricia perennis & + & - & - \\
\hline 28 & Coltricia cinamomea & + & - & 3 \\
\hline 29 & Calocera cornea & + & - & 13 \\
\hline 30 & Hydnellum sp & + & & - \\
\hline \multicolumn{2}{|r|}{ Jumlah } & & & - \\
\hline
\end{tabular}

Keterangan : (+) Ditemukan

(-) Tidak ditemukan

Pada Tabel 5. dapat diketahui bahwa kayu lapuk menjadi habitat yang dominan bagi kebanyakan spesies jamur Makroskopis di lokasi penelitian. Pada penelitian ini ditemukan 13 spesies jamur yang hidup hanya pada kayu lapuk, 5 spesies yang hidup hanya pada tumpukan serasah/tanah dan 3 spesies yang hidup pada pohon hidup. Beberapa spesies jamur Makroskopis dapat hidup pada lebih dari satu habitat, antara lain hidup pada kayu lapuk dan serasah/tanah ada 8 spesies.

Hal ini sesuai dengan pendapat Fuhrer (2011) dalam Syafrizal (2014) yang menyatakan bahwa jamur makroskopis yang terdapat di hutan umumnya tumbuh pada pohon mati/lapuk, dan tanah/serasah daun. Menurut Muchroji (2004) jamur adalah organisme yang tidak berklorofil, sehingga dalam pertumbuhannya jamur memerlukan zat-zat makanan dari proses pelapukan organisme lain yang telah mati.

Berdasarkan substrat pada jamur makroskopis yang ditemukan di Hutan Larangan Adat Rumbio Kecamatan Kampar Kabupaten Kampar, maka dapat diketahui bahwa jamur tersebut memiliki peran penting sebagai dekomposer dalam ekosistem. Hal ini sesuai dengan pendapat Campbell, dkk (2003) dalam Syafrizal (2014) yang 
menyatakan bahwa jamur bersama bakteri merupakan pengurai utama yang dapat mempengaruhi keseimbangan ekosistem dengan menjaga tersedianya nutrien anorganik yang sangat penting bagi pertumbuhan tumbuhan di ekosistem.

Beberapa spesies jamur Makroskopis yang ditemukan di areal penelitian juga bersifat parasit bagi kayu/pohon yang masih hidup. Hal ini sesuai dengan pernyataan McKane dan Kandel (1996) dalam Sari (2015) bahwa beberapa spesies jamur makroskopis bersifat parasit bagi tumbuhan atau hewan. Ditemukan dua spesies jamur pada kayu/pohon yang masih hidup. Spesies tersebut adalah Ganoderma sp, Ganoderma sp1 dan Fomes lignosus. Hal ini sesuai dengan hasil penelitian yang dilakukan Tampubolon (2010) juga menemukan bahwa Ganoderma sp hidup sebagai parasit pada batang pohon yang masih hidup.

\section{KESIMPULAN DAN SARAN}

\section{Kesimpulan}

Berdasarkan hasil penelitian yang telah dilakukan, dapat disimpulkan:

1. Ditemukan 30 jenis jamur Makroskopis dari Divisi
Basidiomycota yang terdiri dari 6 Ordo dan 12 Famili. Ordo Agaricales merupakan kelompok yang mendominasi dalam lokasi penelitian. Jenis yang paling banyak ditemukan adalah dari famili Polyporaceae.

2. Kondisi lingkungan lokasi penelitian yaitu, suhu $24-31^{\circ} \mathrm{C}$, kelembaban udara 75-89\%, intensitas cahaya 125-1226 lux dan $\mathrm{pH}$ tanahnya 5,5-6,4. Jamur Makroskopis yang ditemukan umumnya hidup pada kayu lapuk dan serasah, serta sebagian kecil hidup pada pohon hidup.

\section{Saran}

Diharapkan dilakukan penelitian lebih lanjut untuk mengetahui potensi jamur baik untuk dibudidayakan sebagai bahan pangan maupun juga hanya sebagai bahan informasi penambah wawasan.

\section{DAFTAR PUSTAKA}

Asnah, 2010. Inventarisasi Jamur Makroskopis di Ekowisata Tangkahan Taman Nasional Gunung Leuser Kabupaten Langkat Sumatera Utara. [Tesis]. Program Studi Magister Biologi FMIPA USU. USU Repository. Medan. 
Aswadi, dkk. 2012. Inventarisasi Jamur Makroskopis di Hutan Adat Sungai Kantuk, Kabupaten Sintang, Kalimantan Barat disajikan dalam Seminar Pendidikan Karakter dan Hasil Penelitian IImiah: Eksplorasi Hutan Adat Sungai Kantuk Kabupaten Sintang oleh Mahasiswa Pendidikan Biologi FKIP Untan, Universitas Tanjungpura, Pontianak, 10 Januari.

Devitriana, 2012. Kearifan Lokal Masyarakat Adat Dalam Pelestarian Hutan Larangan Adat Rumbio Kecamatan Kampar Provinsi Riau. Skripsi. Program Studi Pendidikan Biologi FKIP Universitas RiauPekanbaru.

Dwidjoseputro, D. 1978. Pengantar Mikologi, Edisi Kedua. Penerbit Alumni. Bandung.

Fuhrer, B. 2011. A field guide to Australian Fungi. Melbourne: Blooming Books.

Gunawan, A.W. 2001. Usaha Pembibitan Jamur. Jakarta: Penebar Swadaya.

Hasibuan, Sapruddin. 2016. Kajian Ekologi Pasak Bumi (Eurycoma Longifolia Jack) Dan Pemanfaatan Oleh Masyarakat Di Sekitar Hutan Larangan Adat Rumbio Kabupaten Kampar Provinsi Riau [Skripsi]. Jurusan Kehutanan Fakultas Kehutanan.

Hayati, N. 2013. Karakterisasi Morfologi Dan Anatomi Jamur Ektomikorhiza Scleroderma Spp.
Pada Tanaman Melinjo (Gnetum gnemon L.) Di Kabupaten Pacitan. Semarang. [Jurnal]. Tadris Biologi Fakultas Tarbiyah IAIN Walisongo.

Juminarti, L. 2011. Keanekaragaman Jenis Jamur Kayu Makroskopis Dalam Kawasan Hutan Adat Pengajit Desa Sahan Kecamatan Seluas Kabupaten Bengkayang. Skripsi tidak diterbitkan. Pontianak: Fakultas Kehutanan Universitas Tanjungpura Pontianak

Khosuma, A.2012. Keanekaragaman Jamur Makroskopis Pada Altitud Berbeda Di Sepanjang Jalur Pendakian Gunung Bawakaraeng. Makassar. [Skripsi]. Fakultas Matematika Dan IImu Pengetahuan Alam. Universitas Hasanuddin.

Laily, Nur. 2006. Identifikasi Jenis Jenis Ikan Teleostei Yang Tertangkap Nelayan Di Wilayah Perairan Pesisir Kota Semarang.[Skripsi]. FMIPA, Universitas Negeri Semarang.

McKane, L. dan J. Kandel. 1996. Microbiology: Essentials and Applications. McGraw-Hill. New York.

McKnight, K.H. dan Vera B.M. 1987. Mushrooms. New York: Houghton Mifflin Company.

Masriadi. 2011. Profil Hutan Larangan Adat dan Kearifan lingkungan Masyarakat Adat Kenegrian Rumbio. Pekanbaru (unpublinsed). 
Munir, E. 2006. Pemanfaatan Mikroba dalam Bioremediasi: Suatu Teknologi Alternatif untuk Pelestarian Lingkungan. Pidato Pengukuhan Jabatan Guru Besar Tetap dalam Bidang Mikrobiologi FMIPA USU. USU Repository. Medan.

Muniarti, N. 2010. Keanekaragaman Jenis Jamur Kayu Makroskopis Di Hutan Rawa Gambut Pada Plot Permanen Simpur Hutan Desa Kuala Dua Kabupaten Kubu Raya. Skripsi tidak diterbitkan. Pontianak: Fakultas Kehutanan Universitas Tanjungpura Pontianak.

Santoso. 2004. Biologi dan Kecakapan Hidup. Ganeca Exact. Bandung.

Setyosari, P. 2012. Metode Penelitian Pendidikan Dan Pengembangan. Jakarta: Kencana Prenada Media Group.

Sinaga, M.S. 2005. Jamur Merang dan Budi Dayanya. Jakarta: Penebar Swadaya.

Suhardiman, P. 1995. Jamur Kayu. Jakarta: Penebar Swadaya.

Sumarsih, 2003. Diktat Kuliah Mikrobiologi Dasar. Jurusan IImu Tanah, Fakultas Pertanian UPN Veteran Yogyakarta.

Susilowati. 2010. Perbanyakan Tanaman Pasak Bumi(Eurycoma longifolia Jack) Melalui Teknik Stek Pucuk. Bogor. Fakultas Kehutanan IPB.

Syafrizal, S. 2014. Inventarisasi Jamur Makroskopis Di Hutan Adat Kantuk Dan Implementasinya
Dalam Pembuatan Flipbook. [Skripsi]. Pontianak. Program Studi Pendidikan Biologi Jurusan Pmipa. Universitas Tanjungpura.

Tampubolon, et al,. 2010. Keanekaragaman Jamur Makroskopis di Hutan Pendidikan Universitas Sumatera Utara Desa Tongkoh Kabupaten Karo Sumatera Utara. [Jurnal]. Medan. Program Studi Kehutanan, Fakultas Pertanian, Universitas Sumatera Utara.

Uji, T. dan Windadri F.I. 2007. Keanekaragaman Jenis Tumbuhan di Cagar Alam Kakenauwe dan Suaka Margasatwa Lambusango, Pulau Buton Sulawesi Tenggara. Jurnal

Wahyudi, Triroh. 2016. Identifikasi Jenis, Habitat Dan Peranan Jamur Basidiomycota Di Arboretum Dipterocarpaceae Fakultas Kehutanan Universitas Lancang Kuning Pekanbaru. Skripsi

Waluyanti, Maila. 2008. Implementasi Hasil Penelitian Biologi (Studi Keanekaragaman Jamur Basidiomycota) Sebagai Sumber Belajar materi Fungi SMA $X$ Semester Ganjil Kurikulum Ktsp. [Jurnal] Fakultas Keguruan Dan IImu Pendidikan Universitas Sebelas Maret Surakarta. 